\title{
Pemberian Testosterone Replacement Therapy Meningkatkan Ekspresi mRNA Reseptor Androgen pada Kelenjar Prostat Tikus Wistar (Rattus norvegicus) Jantan yang Dikastrasi
}

\author{
Luh Ari Arini \\ Program Magister Ilmu Biomedik Universitas Udayana \\ arikarini.91@gmail.com
}

Diterima: 22 Juni 2016. Disetujui: 30 Juni 2016. Diterbitkan: September 2016

\begin{abstract}
ABSTRAK
Andropause merupakan peristiwa penuaan pada pria yang terjadi secara alami, dimana terjadi penurunan testosteron. Pemberian testosterone replacement therapy dapat memulihkan keadaan defisiensi hormon dan meningkatkan struktur jaringan kelenjar prostat, yang kerjanya dimediasi oleh reseptor androgen. Penelitian ini menggunakan post test only control group design terhadap 36 ekor tikus wistar jantan (21 hari pasca kastrasi). Sampel kelenjar prostat tikus dianalisis ekspresi mRNA reseptor androgen dengan menggunakan metode realtime PCR. Berdasarkan hasil analisis statistik didapatkan rerata ekspresi mRNA reseptor androgen prostat pada kelompok kontrol $(0,57 \pm 0,17 \mathrm{pg} / \mu \mathrm{l})$ dan kelompok perlakuan $(0,77 \pm 0,21 \mathrm{pg} / \mu \mathrm{l})$. Dengan independent-t test $(\alpha=0,05)$, didapatkan bahwa terjadi peningkatan mRNA reseptor androgen secara bermakna pada kelompok perlakuan dimana $p=0,003(p<0,05)$. Disimpulkan bahwa pemberian testosterone replacement therapy dapat meningkatkan ekspresi mRNA reseptor androgen pada kelenjar prostat tikus kastrasi.
\end{abstract}

Kata kunci: testosterone replacement therapy, mRNA reseptor androgen dan kelenjar prostat.

\section{ABSTRACT}

Andropause is the aging process that occurs naturally on men, resulting in a decrease of testosterone. Administration of testosterone to recover of deficiency and can increase the tissue structure of prostate gland which is mediated by androgen receptor. This research used post test only control group design towards 36 castrated male wistar rats (postcastrated 21 days). The androgen receptor expression of mRNA was analyzed by real time PCR method. The result of the statistik analysis reveal that the mean score of prostate androgen receptor expression of mRNA on controlled group was $(0,57 \pm 0,17 \mathrm{pg} / \mu \mathrm{l})$, and $(0,77 \pm 0,21 \mathrm{pg} / \mu \mathrm{l})$ on the treated group. With the independent-t test $(\alpha=0,05)$, indicates that androgen receptor of mRNA increased significantly on the treated group with $p=0,003(p<0.05)$. The study concluded that administration of testosterone replacement therapy increased androgen receptor expression of mRNA in prostate gland of male castrated wistar rats.

Keywords: testosterone replacement therapy, mRNA androgen receptor and prostate gland.

\section{PENDAHULUAN}

Late-onset hypogonadism (LOH) atau andropause secara klinis dan biokimia dijelaskan sebagai penyakit pada pria tua dengan level serum testosteron di bawah parameter normal dari pria muda dan sehat, yang secara alami terjadi pada usia 70-80 tahun. ${ }^{1,2}$ Pria andropause memiliki gejala-gejala defisiensi testosteron seperti penurunan libido, disfungsi ereksi dan ejakulasi, penurunan massa otot dan densitas tulang, peningkatan lemak tubuh, dan masalah psikis yang akhirnya berpengaruh pada kualitas hidup. ${ }^{2}$ Testosteron menurun sekitar satu persen per tahun setelah usia 30 tahun, dengan kriteria kadar testosteron total kurang dari $200 \mathrm{ng} / \mathrm{dl}$ dikatakan sebagai hipogonad. ${ }^{3}$

Defisiensi testosteron akan menyebabkan gangguan pada kelenjar aksesori genital pria termasuk pada kelenjar prostat seperti atropi yang akhirnya akan mempengaruhi volume dari cairan seminal yang penting ketika ejakulasi. Pertumbuhan normal dan diferensiasi epitelium prostat dikontrol oleh androgen dan dimediasi oleh reseptor androgen serta diregulasi oleh sinyal parakrin melalui mekanisme autoregulasi. ${ }^{4}$ Pada kelenjar prostat testosteron dikonversi terlebih dahulu menjadi dihydrotestosterone (DHT) oleh enzim $5 \alpha$-reductase. Androgen (DHT) berinteraksi dengan reseptor androgen (AR) di dalam kelenjar prostat dan akan memacu mRNA di nukleus untuk mensintesis protein sehingga terjadi pertumbuhan kelenjar. Tingkat ekspresi AR dikaitkan dengan peningkatan pertumbuhan lobus kelenjar prostat yang tergantung pada usia, dan ekspresi AR pada organ target ditemukan menurun jika dikaitkan dengan penuaan. ${ }^{5,6}$

Penghambatan proliferasi pada prostat yang dilihat melalui struktur histologi prostat terjadi pada tikus pasca kastrasi, dan dapat dipulihkan kembali dengan pemberian 
testosteron. $^{7}$ Hasil temuan tersebut memberi kesan bahwa pengaruh testosteron pada tingkat jaringan menyebabkan peningkatan pertumbuhan sel pada jaringan tersebut. Perbedaannya pada tingkat molekuler, karena didapatkan bahwa androgen menyebabkan down-regulates level AR mRNA pada ventral prostat tikus, ${ }^{8}$ namun studi selanjutnya mengatakan bahwa androgen menyebabkan up-regulates AR pada prostat, disebabkan karena AR teraktivasi oleh adanya ikatan bersama androgen. ${ }^{9}$ Ekspresi mRNA AR pada kelenjar prostat ditemukan tidak signifikan berbeda antara hewan muda maupun tua. ${ }^{10}$

Pengaruh testosteron pada reseptor androgen berdasarkan penelitian yang lalu masih sangat beragam, namun berdasarkan teori bahwa androgen dapat meningkatkan AR dalam sel yang ditunjukan pada proliferasi sel. Pemberian hormon testosteron dipastikan dapat memelihara organ reproduksi maupun fungsi tubuh secara umum terutama pada usia tua. Testosteron replacement digunakan untuk terapi pengganti hormon testosteron pada pria, yang digunakan ketika terdapat tanda dan gejala klinis dari menurunnya level testosteron, yang bertujuan untuk mengurangi keluhan yang dialami oleh pria hipogonad. ${ }^{11,12}$

Hasil studi pendahuluan pada 10 ekor tikus postkastrasi didapatkan terjadi peningkatan ekspresi mRNA AR pada kelompok yang diberikan testosteron, namun secara statistik tidak signifikan. ${ }^{13}$ Berdasarkan kejadian tersebut dan karena hasil penelitian lalu masih kontroversi maka dilakukanlah penelitian ini untuk membuktikan peningkatan ekspresi mRNA AR pada prostat tikus postkastrasi setelah pemberian testosterone replacement therapy (TRT).

\section{BAHAN DAN METODE Sampel penelitian}

Seluruh sampel yang digunakan pada penelitian yaitu tikus wistar jantan (Rattus norvegicus) yang diternakan di Balai Besar Veteriner Denpasar, usia 20-22 minggu dengan berat badan 250-300 gram sebanyak 36 ekor tikus yang dipilih secara random sampling. Tikus wistar yang dikastrasi pada testisnya, terlebih dahulu dianastesi dengan ketamin $60 \mathrm{mg} / \mathrm{kg} \mathrm{BB}$, dan ditunggu selama 21 hari (terjadi penurunan ekspresi mRNA AR) pada kelenjar prostat. Sampel dibagi menjadi dua kelompok yaitu kelompok kontrol (diinjeksi plasebo/aq secara intramuskuler) dan kelompok perlakuan (diinjeksi Sustanon ${ }^{\circledR} 250$ dosis $4,5 \mathrm{mg} / 250 \mathrm{grBB}$ tikus secara intramuskuler), dengan jadwal injeksi 1 minggu sekali selama 3 minggu/21 hari. Setelah perlakuan berakhir tikus dieutanansia dengan kloroform dan diterminasi untuk pengambilan kelenjar prostat dan diobservasi ekspresi mRNA AR pada masingmasing kelompok.

\section{Persiapan sampel}

Masing-masing sampel kelenjar prostat dipotong dengan ketebalan $5 \mathrm{~mm}$ seberat $20 \mathrm{gr}$ dan dimasukan ke dalam tabung eppendorf yang berisi cairan fiksasi RNA later dengan perbandingan 1:20 dan direndam selama kurang lebih 7 hari, sebelum dianalisis ekspresi mRNA AR menggunakan metode 1 -step q-RT PCR. ${ }^{14}$

\section{Metode analisis realtime PCR}

Setelah sampel pada masing-masing kelompok siap selanjutnya dilakukan ekstraksi RNA dengan suhu $-20^{\circ} \mathrm{C}$ selama 5 hari. Hasil ekstraksi RNA kemudian dilanjutkan dengan kuantifikasi absolut metode 1-step qRT PCR. Amplifikasi dengan mesin PCR akan dilakukan dalam total volume $20 \mu \mathrm{l}$, terdiri dari 100 ng RNA dari sampel, Kapa Sybr Fast 2X, Kapa RT mix (50X), distilled water sampai $20 \mu l$.

Amplifikasi akan dilakukan pada mesin thermal cycler selama 40 siklus. Hasil amplifikasi realtime PCR berupa cycle threshold (Ct) atau ekspresi relatif, kemudian dianalisis kuantitatif menggunakan piranti lunak REST untuk mendapatkan nilai absolut/mutlak. ${ }^{14}$ Ekspresi absolut yang didapat dilanjutkan dengan analisis statistik. ${ }^{15}$ Seluruh pelaksanaaan penelitian ini dilakukan di Laboratorium Histologi Fakultas Kedokteran Universitas Udayana.

\section{Analisis data}

Data yang didapat dari penelitian ini disusun dalam bentuk tabel dan dianalisis secara statistik menggunakan program SPSS 21. Analisis normalitas menggunakan uji Shapiro wilk dan homogenitas menggunakan Levene's test, menunjukan data pada masing-masing kelompok sampel berdistribusi normal dan homogen sehingga menggunakan uji statistik parametrik independent- $t$ test dengan taraf kemaknaan $(\alpha=$ $0,05)$.

HASIL

Pemeriksaan ekspresi mRNA AR secara umum dapat diperiksa menggunakan realtime PCR (RT-PCR). Hasil yang didapatkan berupa angka dan grafik, sehingga dapat dilakukan uji kuantitatif. Hasil amplifikasi dari mesin PCR dimasukan dalam rumus ( $Y=$ slope $\operatorname{Ln}(X)+Y$-int), nilai Slope $Y$ dan $Y$-int didapat saat pembuatan kurva standar androgen. Nilai Y adalah Ct yang didapatkan dari hasil mesin realtime PCR. Kurva standar androgen juga dibuat dengan metode realtime PCR. Rumus tersebut 
digunakan untuk menentukan ekspresi absolut kuantifikasi $\Delta \Delta \mathrm{Ct}$ atau konsentrasi $\mathrm{X}$ (yaitu kadar mRNA), yang mana jika dimasukan ke dalam rumus menjadi: kadar $\mathrm{mRNA}=\operatorname{Exp}(\mathrm{Ct}-\mathrm{Y}$-Int $) /$ Slope. ${ }^{14}$ Kadar mRNA dalam satuan $\mathrm{pg} / \mu \mathrm{l}$ yang didapat dari piranti lunak REST dilanjutkan dengan menggunakan analisis statistik. Analisis efek perlakuan diuji berdasarkan rerata ekspresi mRNA reseptor androgen antara kelompok kontrol dan kelompok perlakuan (Tabel 1).

Tabel 1

Perbedaan rerata ekspresi mRNA AR antara kelompok kontrol dan perlakuan

\begin{tabular}{cccccc}
\hline Kelompok & $\mathbf{n}$ & $\begin{array}{c}\text { Rerata } \\
(\mathbf{p g} / \boldsymbol{\mu l})\end{array}$ & SD & $\boldsymbol{t}$ & $\mathbf{p}$ \\
\hline Kontrol & 18 & 0,57 & 0,17 & & \\
& & & & $-3,19$ & 0,003 \\
Perlakuan & 18 & 0,77 & 0,21 & & \\
\hline
\end{tabular}

Berdasarkan tabel di atas, menunjukan bahwa rerata ekspresi mRNA AR prostat pada kelompok kontrol adalah $0,57 \pm 0,17 \mathrm{pg} / \mu \mathrm{l}$ dan kelompok perlakuan adalah 0,77 $\pm 0,21 \mathrm{pg} / \mu \mathrm{l}$. Analisis kemaknaan dengan independent- $t$ test, menunjukan nilai $t=-3,19$ dan nilai $p=0,003$. Berdasarkan hal tersebut berarti bahwa rerata ekspresi mRNA AR pada kedua kelompok berbeda secara bermakna $(p<0,05)$. Ekspresi mRNA reseptor androgen pada kelompok perlakuan yang dikastrasi dan diberikan hormon testosteron lebih besar daripada kelompok kontrol yang hanya dikastrasi (Gambar 1).

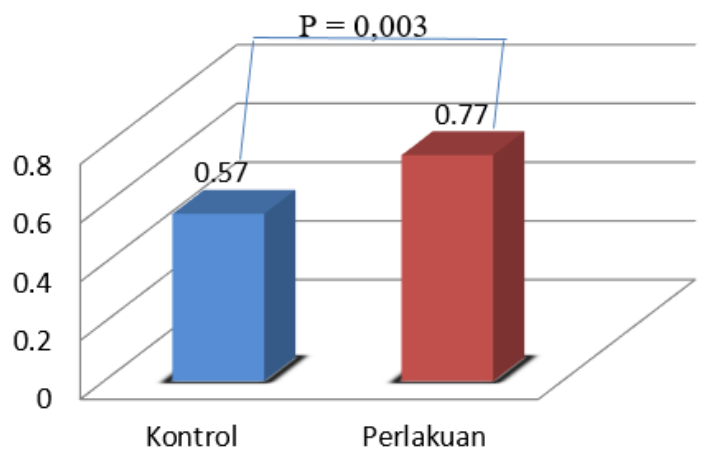

Gambar 1.

Perbandingan ekspresi mRNA AR antara kelompok kontrol dan kelompok perlakuan. ekspresi mRNA AR klp. kontrol (biru) 0,57 pg/ $\mu \mathrm{l}$ dan klp. perlakuan (merah) $0,77 \mathrm{pg} / \mu \mathrm{l}$. Didapatkan terjadi peningkatan ekspresi mRNA AR $(p=0,003<\alpha)$ $(0,05)$.
DISKUSI

\section{Penurunan Ekspresi mRNA AR Prostat Pasca Kastrasi}

Rerata ekspresi mRNA AR prostat pada kelompok kontrol lebih rendah dibandingkan dengan kelompok perlakuan, hal ini membuktikan bahwa kastrasi tanpa disertai dengan TRT, menyebabkan keadaan defisiensi testosteron menjadi menetap sehingga ekspresi AR di dalam jaringan prostat lebih rendah. Reseptor androgen merupakan ligand-activated faktor transkripsi yang memediasi sinyal dari semua androgen termasuk DHT, yang merupakan androgen terbesar terkait dengan perkembangan prostat dan aktivitas AR pada jaringan target tergantung pada $A R$ signalling. ${ }^{16,17}$

Penghilangan androgen dengan cara kastrasi akan menimbulkan kegagalan dari proses sintesis AR di dalam sel targetnya seperti pada prostat. Oleh karena tidak adanya ikatan bersama antara reseptor dan ligannya menyebabkan proses (mekanimse autoregulasi) terhenti, yang akhirnya akan mempengaruhi sintesis protein di dalam selsel kelenjar prostat. Defisiensi androgen akan menimbulkan penurunan AR message/ $\mu$ g DNA dan jika tidak dipulihkan kembali maka akan menimbulkan masalah, yaitu selain mempengaruhi organ reproduksi juga akan mempengaruhi fungsi tubuh secara keseluruhan.

Konsentrasi AR message di dalam sel yang menurun bahkan menghilang akibat kastrasi, menyebabkan degradasi dari gen AR hasil transkrip (mRNA AR), yang merupakan produk secretory utama pada suatu region seperti pada kelenjar prostat. ${ }^{18}$ Oleh karena tidak adanya androgen yang menstimulasi AR maka menyebabkan kompleks Androgen-AR (AR-dependent) tidak terbentuk. Pada ketiadaan hormon androgen, menyebabkan reseptor androgen monomers berikatan kembali bersama seluler chaperones seperti protein heat shock (HSP90, HSP70, HSP56 dan immunophilins), sehingga reseptor menjadi inaktif kembali. Protein-protein tersebut berperan secara tidak langsung dalam perubahan bentuk reseptor terutama dalam efisiensi ligand binding domain (LBD). ${ }^{17}$

Berdasarkan penelitian lalu membuktikan bahwa pada penyakit diabetes melitus diketahui dapat menurunkan ekspresi AR yang dijelaskan secara genomic, terjadi proses methylation DNA. Proses metilasi merupakan peristiwa penambahan gugus metil $\left(\mathrm{CH}_{3}\right)$ pada atom $\mathrm{C}$ nomer 5 dari cincin pirimidin (citosin) pada eukariot atau cincin purin (adenin) pada prokariot, yang mengakibatkan terjadinya silencing pada ekspresi gen. Gugus metil akan hilang pada pembentukan zigot, tapi prosesnya berangsur-angsur kembali selama tahap 
perkembangan seiring dengan pertambahan usia. Proses metilasi dari residu sitosin dapat mengakibatkan DNA yang aktif menjadi tidak aktif. Hipogonadisme yang disebabkan karena penyakit diabetes mengakibatkan sel-sel mengalami penurunan fungsi dan dapat dipastikan telah terjadi metilasi DNA sama halnya dengan yang terjadi pada penuaan namun hanya sebagian. ${ }^{14,19}$ Pada peristiwa metilasi terjadi perubahan struktur kromatin dan silencing ekspresi gen sehingga sangat dikaitkan dengan terjadinya proses penuaan. Aktivitas DNA metiltransferase ini merupakan mekanisme yang penting untuk penurunan genomic DNA selama proses penuaan. $^{19}$

Berdasarkan hal tersebut, bahwa pada kastrasi juga terjadi methylation DNA AR pada bagian promoter (region yang kaya protein citosin dan guanin $/ 5^{\prime} \mathrm{CpG}$ dinukleotida) dan modifikasi histon yang menyebabkan ikatan dengan faktor transkripsi menurun sehingga DNA AR tidak dapat menjalani proses transkripsi (transkripsi inaktif) untuk membentuk gen AR hasil transkrip, sehingga menurunkan ekspresi mRNA AR dan protein pada prostat. In vitro metilasi DNA dari 5'CpG AR dinukleotida dikaitkan dengan hilangnya ekspresi AR dan reexpression dikaitkan dengan region demetilasi. $^{20}$

Kompleks androgen-AR secara kuat berhubungan dengan RNA (bentuk cytoplasmic ribonucleoproteins dan nuklear). Defisiensi androgen setelah kastrasi akhirnya akan menyebabkan hilangnya hubungan AR-RNA dan fungsinya. ${ }^{18}$ Oleh karena itu akan menimbulkan penyusutan jaringan seperti yang terjadi pada kelenjar prostat sehingga produksi cairan seminal menjadi berkurang.

\section{Peningkatan ekspresi mRNA AR pada prostat setelah pemberian testosterone replacement therapy}

Peningkatan ekspresi mRNA AR pada prostat secara bermakna pada kelompok perlakuan $(p<0,05)$ sebesar $35 \%$. Berdasarkan kejadian tersebut, terbukti bahwa testosteron dapat memulihkan keadaan defisiensi yang sebelumnya terjadi. Secara genomic pemberian hormon testosteron menyebabkan peristiwa metilasi DNA AR pada prostat yang sebelumnya terjadi akibat kastrasi akan mengalami demetilasi regulator (penghilangan gugus metil), sehingga gen menjadi aktif dan regulasi transkripsi mulai berlangsung kembali atau AR diekspresikan kembali menjadi androgen responsif gen. ${ }^{20}$ Berdasarkan hal tersebut, menunjukan bahwa pada kelompok perlakuan terjadi up regulates ekspresi mRNA AR pada prostat oleh karena pemberian testosteron.

Penelitian sebelumnya, mengatakan bahwa androgen menyebabkan up-regulates dari AR pada prostat, hal ini disebabkan karena AR teraktivasi oleh karena adanya ikatan bersama androgen serta peningkatan sintesis dan half-life merupakan respon sel terhadap hormon androgen, $9,21,22$ sehingga akan menghasilkan peningkatan dari level reseptor protein di dalam jaringan.

Ekspresi mRNA AR pada prostat yang mulanya menurun dipulihkan dengan pemberian testosteron replacement, hormon testosteron setelah memasuki sel-sel targetnya dimetabolisme menjadi $5 \alpha$-DHT oleh enzim $5 \alpha$-redukatse type $2 .^{10}$ Dihidrotestosteron akan menstimulasi reseptor androgen yang mulanya inaktif di dalam sitoplasma prostat untuk berikatan bersama membentuk kompleks androgen-AR (DHT-AR), sehingga menghasilkan perubahan bentuk reseptor seperti pengaktifan AR dan pelepasan seluler chaperones. Proses ikatan tersebut dipengaruhi oleh AR signalling (cAMP, cGMP dan ligase), jika AR signalling meningkat oleh karena pengaruh androgen, maka menyebabkan peningkatan juga pada mekanisme posttranskripsi mRNA AR, mRNA processing, transport dan stabilitas mRNA AR serta AR messages juga mulai beregulasi kembali. ${ }^{17}$

Hormon yang berdifusi ke dalam sel selain berikatan dengan reseptor di cytoplasmic dan membentuk kompleks androgen-AR juga berikatan dengan reseptor nuclear. Kompleks androgen-AR yang telah aktif disebut juga AR-dependent, mengalami dimerisasi dan translokasi menuju nukleus. Reseptor androgen dimer akan berikatan dengan squence DNA spesifik (pada bagian promoter) yang dikenal sebagai sequence androgen respone elements (AREs) dan membentuk DNA-binding. Promoter DNA merupakan sequence yang dikenali pertama kali oleh RNA polimerase II (protein regulator) untuk menjalankan proses transkripsi. Protein lain termasuk coactivators dan faktor transkripsi juga akan berikatan pada DNA dan kompleks androgenreseptor tersebut, selanjutnya menghasilkan transkripsional yang aktif. ${ }^{23}$ Gen target (mRNA) sebagai hasil transkripsi di nukleus akan ditranslasi oleh ribosom di sitoplasma untuk memproduksi protein spesifik, dan hasil sintesis protein itulah yang akan menimbulkan terjadinya respon sel berupa proliferasi dan diferensiasi sel pada target organ termasuk pada kelenjar prostat. ${ }^{24}$

Defisiensi androgen akan menurunkan kapasitas binding dari AR, dan dapat dipulihkan dengan pemberian TRT. ${ }^{25}$ Pembentukan ARdependent dapat menyebabkan pemulihan secara 
Proliferative Response Of The Ventral Prostate

cepat dari AR ligand binding, yang terjadi setelah pemberian hormon androgen. Kelimpahan androgen akan merangsang timbulnya AR untuk membentuk suatu ikatan dengan androgen, yang akan mengalami pengaktifan dan dimerisasi reseptor dan siap berikatan kembali bersama DNA di dalam nukleus. Ketiadaan pengiriman pesan ke nuklear oleh AR message pada ketiadaan androgen, akan menyebabkan akumulasi pesan di dalam nukleus, sehingga menimbulkan sintesis protein tidak dapat berjalan.

\section{SIMPULAN}

Berdasarkan hasil penelitian dapat disimpulkan bahwa pemberian testosterone replacement therapy meningkatkan ekspresi mRNA reseptor androgen pada kelenjar prostat tikus wistar (Rattus norvegicus) jantan yang dikastrasi.

\section{DAFTAR PUSTAKA}

1. Cunningham, R., Hijazi, A., Glenn. Androgen Replacement Therapy Indicated for the Aging Male. Departments of Medicine and Molecular and Cellular Biology, Baylor College of Medicine and VA Medical Center, Houston. Annual review. 2004;56:137-117.

2. Nieschlag, E., Swerdloff, R., Behre, H.M. Investigation, Treatment, and Monitoring of Late-Onset Hypogonadism in Males: ISA, ISSAM, and EAU Recommendations. Int J Androl. 2005;28:127-125.

3. Borst, S.E., Mulligan, T. Testosterone Replacement Therapy for Older Men. Clinical Interventions in Aging. PMC. Ncbi. 2007; 4:2:328-322.

4. Gao, N., Ishii, K., Mirosevich, J., Kuwajima, S., Stacey, R., Richard, L., Jiang, M., Scott, B., Richard, M., Stoffel, M. Article Forkhead Box A1 Regulates Prostate Ductal Morphogenesis and Promotes Epithelial Cell Maturation. Company of Biologists. 2005;132:3443-3431.

5. Banerjee, P., Banerjee, S., Brown, T.R. Increased Androgen Receptor Expression Correlates With Development Of AgeDependent, Lobe-Specific Spontaneous Hyperplasia Of Rat Prostate. Endocrinology. 2001;142:4075-4066.

6. Prakash, C., Supakar, Chung, S., Song, M., Jung, M. A., Slomczynska, J.M., Kim, R. L. Vellanoweth, B.C., Adrun, K.R. A Novel Regulatory Element Associated with Agedependent Expression of the Rat Androgen Receptor Gen. The Journal of Biological Chemistry. 2003;268:35:2640-2610.

7. Justulin, J.R., Rodrigo, L.A, Ureshino, P., Michelle, Z., Felisbino, S.L. Differential
And Seminal Vesicle To Testosterone Replacement. International Federation For Cell Elseiver Ltd. Biology. 2006;30:364-354.

8. Zhu, L.J., Matthew, H.P., Bardin, W., Alfred, J. Effects of Androgen on Androgen Receptor Expression in Rat Testicular and Epididymal Cells. Biology of Reproduction. 2000;63:376368.

9. Takeda, H., Nakamoto, T., Kokontis, J., Chodak, G., Chang, C. Autoregulation Of Androgen Receptor Expression In Rodent Prostate: Immunohstochemical And In Situ Hybridization Analysis. Biochem Biophys Res Commun. 2001;177:496-488.

10. Shidaifat, F. Age-Dependent Expression of 5aReductase and Androgen Receptors mRNA by the Canine Prostate. Department of Basic Veterinary Medical Sciences, Faculty of Veterinary Medicine. Jordan. Physiol. Res. 2009;58:158-155.

11. Surampudi, P.N., Wang, C., Swerdloff, R. Hypogonadism in the Aging Male Diagnosis, Potential Benefits, and Risks of Testosterone Replacement Therapy. Journal of Endocrinology. 2014;20:259-254.

12. Dandona, P., Dhindsa, S., Chandel, A., Topiwala, S. Low Testosterone in Men with Type 2 Diabetes - A Growing Public Health. Diabetes Voice. 2009;54:567-560.

13. Arini, L.A. "Pemberian Testosteron Replacement Meningkatkan Ekspresi mRNA Reseptor Androgen Pada Kelenjar Prostat Tikus Wistar (Rattus norvegicus) Jantan Yang Di Kastrasi" (penelitian pendahuluan). Denpasar: Universitas Udayana. 2016.

14. Kim, J.W., Yoon, M.M., Bae, C.Y., Kim, J.J., Moon, D.G. The Effect of Diet-Induced Insulin Resistance on DNA Methylation of the Androgen Receptor Promoter in the Penile Cavernosal Smooth Muscle of Mice. Asian Journal of Andrology. 2013;15:491-487.

15. Dahlan, M. S. Statistika untuk Kedokteran dan Kesehatan. Jakarta: Salemba Medika. 2012:174-167,187-184,208-189.

16. Verrijdt, G., Haelens, A., Claessens, F. Selective DNA Recognition By The Androgen Receptor As A Mechanism For Hormone-Specific Regulation Of Gene Expression. Molecular Genetics and Metabolism. 2003;78:185-175.

17. Zhu, M.L and Kyprinaou, N. Androgen Receptor And Growth Factor Signaling Cross-Talk In Prostate Cancer Cells. Endocr. Relat. Cancer. 2008;15:4:849-841.

18. Liao, S. Receptors And The Mechanism of Action Of Androgens. In: Receptors And Mechanism of Action of Steroid Hormones. 
2nd Ed. New York : Marcel Dekker. 2006:214159.

19. Kim, K.C., Friso, S., Choi, S.W. DNA Methylation, An Epigenetic Mechanism Connecting Folate To Healthy Embryonic Development And Aging. J. Nutritional Biochemistr. 2009;20:926-917.

20. Maegawe, S., Hinkal, G., Kin, H.s. Widepread And Tissue Specific Age-Related DNA Methylation Changes In Mice. Genome Res. 2010;20:340-332.

21. Sanborn, B.M., Caston, L., Chang, C., Speller, R., Porter, L. Regulation of Androgen Receptor mRNA In Rat Sertoli and Peritubular Cells. Biology of Reproduction. 2001;45:641-634.

22. Marilia, T.C., Erick, J.., Cristina, M., Avelar, W. Androgen and the Male Reproductive Tract. Endocrinologi Experimental, Departement Farmacology Universitas Federal Sao Paulo Brasil. Arq. Bras. Endocrinol Metab. 2009;53:8:945-934.
23. Weigel, N.L., Zhang, Y., Ligand-Independent Activation Of Steroid Hormone Receptors. Springer-Verlag. J Mol Med. 2008;76:479-469.

24. Haelans, A., Verrijdt, G., Callewaert, L., Peeters, B., Rombauts, W., Claessens, F. Androgen Receptor-Specific DNA Binding to An Element in the First Exon of the Human Secretory Component Gene. Biochem. J. 2001;353:3:620611.

25. Paris, F., Weinbaver, G.F., Blum, V., Nieschlag, E. The Effect Of Antiandrogens On The Immunohistochemical Localization of The Androgen Receptor In Reproductive Organs Of Male Rats. J. Steroid Biochem. 2004;48:137129.

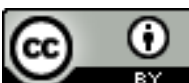

This work is licensed under a Creative Commons Attribution 